\title{
Practical Guidelines for Estimation of Rest Area Use on Rural Interstates and Arterial Highways
}

\section{Authors: Ahmed Al-Kaisy, David Veneziano, Zachary Kirkemo, and Christopher Dorrington}

This is a postprint of an article that originally appeared in Transportation Research Record on January 2012. The final version can be found at https://doi.org/10.3141/2303-13.

Al-Kaisy, Ahmed, David Veneziano, Zachary Kirkemo, and Christopher Dorrington. "Practical Guidelines for Estimation of Rest Area Use on Rural Interstates and Arterial Highways."

Transportation Research Record 2303, no. 1 (January 2012): 117-124. doi:10.3141/2303-13. 


\title{
Usage Estimation at Rest Areas on Rural Interstate and Arterial Highways: Practical Guidelines
}

Paper 12-3352

\author{
Ahmed Al-Kaisy, David Veneziano, Zachary Kirkemo and Christopher Dorrington
}

\author{
Ahmed Al-Kaisy Ph.D., Associate Professor \\ Department of Civil Engineering \\ Montana State University \\ 213 Cobleigh Hall, Bozeman, MT 59717 \\ Phone: (406) 994-6116, Fax: (406) 994-6105, Email: aalkaisy@ce.montana.edu \\ David Veneziano Ph.D., Research Scientist \\ Western Transportation Institute, Montana State University \\ P.O. Box 174250 \\ Bozeman, MT 59717-4250 \\ Phone: (406) 994-6320, Fax: (406) 994-1697, Email: david.veneziano@coe.montana.edu \\ Zachary Kirkemo, Graduate Research Assistant \\ Western Transportation Institute \\ Montana State University \\ Phone: (406) 580-3669, Email: Zachary.Kirkemo@msu.montana.edu \\ Christopher Dorrington, Transportation Planning Manager \\ Montana Department of Transportation \\ 2550 Prospect Avenue \\ P.O. Box 201001 \\ Helena, MT 59620-1001 \\ Phone: (406) 444-7239, Fax: (406) 444-7671, Email: cdorrington@mt.gov \\ 4800 words \\ 10 Tables, 1 Figure \\ 7550 words total
}


Al-Kaisy, et al.

\begin{abstract}
Rest areas perform a critical role in the highway network. They provide passenger vehicle occupants and heavy vehicle operators with an opportunity to use a restroom, walk around, stop for a meal, sleep for a period of time, or even pause to use a cellular phone. These activities also have a direct impact on the various aspects of rest area planning and design. Existing guidance for rest area planning and design are largely based on national trends which may not represent usage patterns in rural states. This paper presents a series of practical guidelines that may be employed in the design and rehabilitation of rest area facilities, particularly those in rural areas. The guidance was developed using empirical observations of rest area usage at 44 study sites in the state of Montana. Given the amount of data collected and used in this research, it is reasonable to expect that the developed guidelines are representative of a significant proportion of existing and future rest area sites in rural locales. However, each rest area is different and careful consideration should be given when employing the guidelines outlined in this paper.
\end{abstract}

Keywords: rest areas, rural highways, usage estimation, guidelines, heavy vehicles. 


\section{INTRODUCTION}

Rest areas perform a critical role in the highway network. They provide passenger vehicle occupants and heavy vehicle operators with an opportunity to use a restroom, walk around, stop for a meal, sleep for a period of time, or even pause to use a cellular phone. Many of these activities aid in reducing driver fatigue, with the potential for consequently reducing fatiguerelated crashes. These various activities also have a direct impact on a number of aspects of rest area design, from parking stall demand to facility sizing, water needs and wastewater generation and handling.

For decision-making related to rest area usage, many states consult the American Association of State Highway and Transportation Officials (AASHTO) "A Guide for the Development of Rest Areas on Major Arterials and Freeways" (1). This reference provides guidance related to rest area design, including water and sewer system capacity, as well as parking lot size and layout. However, the figures provided in this document for various rest area design aspects are based on national averages which may not represent usage patterns in rural states. This limitation in the aforementioned guidance was deemed a significant knowledge gap which needs to be addressed given the different travel patterns and needs of rural areas.

Rest areas located along lower-volume rural roadways may receive higher percentages of mainline volumes than those estimated by AASHTO, owing to longer distances between towns or less developed areas, and thus fewer opportunities to stop. If traffic volume estimates for a rest area are inaccurate, then other usage estimates needed for sizing and design may be inaccurate as well. Consequently, a facility may end up being under-designed, requiring costly future renovations and expansion, or over-designed, wasting scarce financial resources.

For the aforementioned reasons, research was undertaken to develop guidance for the estimation of rural rest area usage, including vehicle traffic counts and classifications, water flow, effluent flow, pedestrian traffic, and vehicle dwell times for commercial and passenger vehicles. The aim was to provide a comprehensive understanding of these aspects of rural rest area usage so that future design decisions and rehabilitation planning could be better supported by using empirically derived, more accurate estimates.

\section{LITERATURE REVIEW}

The following sections briefly summarize literature related to various aspects of rest areas, with a specific focus on rest area usage estimation aspects such as vehicular and patron usage estimation, dwell time, water usage and wastewater estimation.

\section{Traffic Count Estimation}

For decision making related to rest area usage, many states consult the AASHTO Guide for the Development of Rest Areas on Major Arterials and Freeways (1). Aside from the AASHTO guidance, remaining literature was either dated $(2,3,4)$ or employed limited sample sizes $(5,6)$. Therefore, the results of these studies may not necessarily represent current conditions because of traffic growth over time or site-specific trends that skew results in the case of small samples. A more recent study by Al-Kaisy, et al. whose data was used in developing the guidance of this work sought to address these limitations (7). A summary of the results from all literature is provided in Table 1. As shown in this table, the percentage of mainline traffic entering rest areas varies in a wide range between 0.5 to 21.5 percent.

\section{Dwell Time}


Similar to the guidance developed for rest area usage rates, identified dwell time data was also dated $(2,3,8,9,10)$. The results of these studies are summarized in Table 1. Given that travel patterns may have changed over the past few decades, it was unclear whether the guidance provided was still applicable, particularly in a rural context.

\section{Water Use and Wastewater}

In addition to traffic-related guidance, the AASHTO rest area guide presents information with respect to water usage at rest area sites (1). The guide recommends that restroom facilities be split with $60 \%$ for women and $40 \%$ for men, based on the assumption that women will utilize the restroom for a longer duration. Further, the guide provides an equation to estimate water usage employing a variety of traffic and patron data and factors, along with an assumed 13.25 liters (3.5 gallons) of water used per person. Aside from the guidance provided by the AASHTO guide, only a limited number of additional studies $(4,5)$ provided information for water use and effluent water generated at rest areas. The key findings of these references were that 70 percent of vehicle occupants used restrooms, the mix of patrons was 40 percent men and 60 percent women, water usage ranged between 3.0 and 7.3 gallons per vehicle, and the water to wastewater ratio was approximately $1: 1$.

\section{RESEARCH MOTIVATION}

As the previous section indicated, nearly all of previous studies on rest area usage are outdated as they were conducted more than 20 years ago. Further, most of those studies used a limited number of sites that may not well represent rest area usage aspects in some of the more rural states in the country. Therefore, up-to-date, comprehensive guidance on rest area usage in rural areas is needed to support the planning, design and rehabilitation of rest areas in some of the more rural states in the country.

\section{STUDY DESIGN}

\section{Study Sites}

Data was collected at 44 state-maintained rest areas throughout the state of Montana. These rest areas represented a wide range of design layouts, facility condition, highway type served, and proximity to developed areas. Thirty of these rest areas were located on interstate facilities, leaving 14 rest areas on non-interstate principal and minor arterials.

\section{Data Collection and Processing}

\section{Traffic Count Data}

Due to the large number of study sites, it was necessary for a sampling technique to be employed in order to obtain the data needed using reasonable resources, i.e., equipment, personnel, and cost. The methodology called for collecting traffic data at representative rest areas (control stations) for the peak summer travel season, while collecting short-term traffic data at all other locations (coverage stations). Control stations were selected to represent different highway classifications and traffic levels. Interstate highways and other major/minor Arterial routes (mainly rural arterials) were used for highway class. Two levels of AADT were used to classify sites by traffic level on the two categories of highway classes (high-volume Interstate AADT $\geq$ 5000, low-volume Interstate AADT $<5000$, high-volume Arterial AADT $\geq 3000$, and lowvolume Arterial AADT < 3000). 
Portable traffic counters were installed at the entrance of the rest area at each study site to obtain traffic count and classification of vehicles entering the rest areas. Automatic Traffic Recorders (ATRs) were used when available to estimate mainline traffic. When these counts were not available, 36-hour sample counts were obtained and expanded to estimate the hourly mainline traffic counts during the period of rest area traffic data collection. Daily and monthly factors were derived using trends observed from selected ATRs to represent other short-term sample count stations used in this study. All mainline traffic data from the ATRs and the shortterm sample counts were provided by the Montana Department of Transportation (MDT).

The proportion of vehicles exiting the mainline and entering the rest area was estimated by dividing the number of vehicles entering the rest area by the mainline traffic count every hour.

\section{Dwell Time Data}

Dwell time is defined as the time elapsed from the moment a vehicle occupies a parking stall to the moment it leaves the parking stall and is important in estimating parking needs. Dwell time data was collected using surveillance cameras on mobile trailers at three representative study sites for a duration of one week each. Two study sites are located on interstate highways and one study site on a state highway route. The surveillance cameras were set to overlook the overall parking area, including the auto and heavy vehicle parking stalls. The video records were manually processed to determine the time a vehicle entered and left the rest area, with vehicles classified as 1) passenger vehicles; 2) trucks and buses; and 3) recreational vehicles (RVs).

\section{Patron Counts and Water Use Data}

Automatic door counters and water meters were installed by MDT Facilities Bureau and District Maintenance personnel at all rest areas investigated. The door counters recorded the number of door openings, which is a good indicator of the number of patrons entering and leaving the rest area building. The water meters recorded the quantities of water being used at each site (meters were placed such to record only rest-area related use and not sprinklers, etc.). The MDT rest area caretakers recorded and reset the door counters each morning between 6:00 a.m. and 8:00 a.m., along with a water meter reading.

\section{STUDY RESULTS}

The analyses performed on the data gathered over the course of this research provided some practical guidelines for rest area usage estimation. These analyses are presented in the following sections.

\section{Overall Traffic Usage at Rest Areas}

Table 2 provides a summary of the descriptive statistics for the daytime peak period traffic usage that were determined in the course of this research, with additional statistics combining the data from the interstate and non-interstate facilities. From a practical standpoint, rest area usage during the peak period has more significance in the planning and design of rest area facilities than other periods during the day. For dual interstate sites, the percentage applicable to each direction of travel was used.

As shown, the rest areas in the low-volume arterial category were associated with higher mean rest area traffic usage and standard deviation compared with the other three categories. This was also applicable to the percentile usage values. For the other three categories, the mean rest area usage and standard deviation were relatively close to one another. 
It is important to mention that the high-volume arterial category included only four rest areas that did not share many other similar attributes to one another. Rest area usage at the control station for the group was notably lower than that at the other three rest areas, which could be related to seasonal and recreational traffic. Further, two of the four rest areas in this category were adjacent to weigh station facilities that may have an influence on usage (induced demand, primarily of commercial vehicles). On the other hand, the low-volume arterial category included a higher number of sites that are considered more uniform or homogeneous. Therefore, there is a strong reason to believe that traffic usage observations at rest areas in the low-volume category are more representative of rest areas on arterials in general than those collected from rest areas in the high-volume category.

Upon careful examination of Table 2, it may be reasonable to suggest that using 16 percent of the interstate mainline peak traffic as a baseline rest area traffic usage will ensure that the rest area design will accommodate the peak mid-day traffic around 85 percent of the time. Similarly, using a baseline rest area usage of 25 percent at rest areas on arterials in general will accommodate the peak mid-day traffic slightly less than 85 percent of the time. The latter recommended value, while slightly lower than the $85^{\text {th }}$ percentile, is deemed appropriate given the high variation in usage observations associated with rest areas in the low-volume arterial category.

\section{Heavy Vehicle Traffic Usage}

In examining heavy vehicle usage, the mainline truck proportion did not exhibit a consistent relationship with the percentage of rest area usage. Therefore, a more in-depth analysis was performed on the high and low volume interstate and low volume arterial control sites for which mainline truck proportion data was available. Using data from the respective mainline ATRs, the mainline truck proportion was compared to the percentage of rest area usage by hour. The results of this analysis at the high and low volume interstate control station sites are presented in Table 3. The low volume arterial site was excluded due to the low average percentage of trucksError! Reference source not found..

An examination of Table 3 shows that rest area usage slightly declines with the increase in the percentage of heavy vehicles up to around 30 percent and then starts to increase again when the percentage of heavy vehicles reaches 40 percent or higher. It is suspected that the increase in usage associated with the high heavy vehicle percentage is related to off-peak late night and early morning hours.

Therefore, it was decided to exclude the off-peak period from the analysis. Table 4 shows the rest area usage for various levels of mainline heavy vehicle percentages for the period between 8:00 a.m. and 8:00 p.m. This table shows that there is no clear trend related to the effect of heavy vehicles on the rest area usage. The increase at the low volume interstate site associated with the high truck percentage is based on a few observations and therefore cannot be treated with certainty. Based on the values presented in Table 4, it is reasonable not to adjust rest area usage based on daytime truck percentage.

To further examine the relationship between rest area usage and heavy vehicles percentage, the average heavy vehicle proportion was calculated during the designated peak period (9 a.m. - 4 p.m.) and compared to the overall average truck proportion, as presented in Table 5. This analysis proves that the truck proportion increases significantly during off-peak hours. Based on the percentages of heavy vehicles presented in Table 5, it would be reasonable to use 70 percent of the overall heavy vehicle percentage for the highway served by the rest area in determining the number of heavy vehicle parking stalls required at a particular rest area. This 
estimation is relatively conservative as, at most sites investigated by this research, it exceeds the actual number of trucks using the rest area during the peak design hours. This is especially true for rest areas located at highways that fall in the low-volume interstate and arterial categories.

As parking stalls for commercial vehicles are different from those used for smaller vehicles, it was deemed appropriate to examine the heavy vehicle counts and percentages entering the high and low volume interstate rest areas. The results of this analysis are shown in Figure 1. As shown, the number of heavy vehicles entering rest areas on average is higher during the day as more travel occurs during the day. Specifically, the number of heavy vehicles using a rest area peaks mid-day around noon despite the fact that the percentage of trucks in the mainline traffic stream peaks after midnight (roughly during the period between 1:00 a.m. and 4:00 a.m.). Therefore, estimates of mid-day and nighttime heavy vehicle counts along with the expected dwell times are important inputs for the determination of parking needs at rest areas.

\section{Parking Dwell Times at Rest Areas}

Parking dwell time is a critical input in determining the parking demand and design capacity at a particular rest area both for passenger and commercial vehicles. When data were separated by day and night, average dwell time during the day was found to be significantly lower than that during the night as shown in Table 6. At the three rest areas investigated, the mean truck dwell time during the night is roughly around 4 to 5 times that during the day. However, the number of trucks using the rest area during daytime is higher than that during nighttime. Therefore, both truck count and mean dwell time during the day and night should be used in determining the number of truck parking stalls needed at the subject rest area. This is not the case with the passenger vehicles, where daytime counts usually dictate the parking needs at the rest area. The reader should note however, that the provision of truck stalls at rest areas is not intended to solve truck parking shortages, and the proximity and capacity of private truck stops should be considered during design.

\section{Weigh Stations}

During the research, observations of the operation of a weigh station in conjunction with a rest area appeared to increase the rest area usage at a particular site. To further examine this, the percentage of rest area usage was calculated during periods when the weigh stations were both closed and open and the results are presented in Table 7. Only daytime hours when the weigh stations were in operation were used in this comparison.

As shown in Table 7, rest area usage dramatically increased during the hours of weigh station operation at sites 2 and 3, but exhibited almost no change at site 1 . The site 1 rest area and weigh station are set apart from one another, though they share the same driveway access. This differs slightly from the layout of sites 2 and 3, which may partly explain the lack of change in usage observed at study site 1. Another possible factor behind this was the proximity to major cities. This may have an effect on the induced demand on the rest area from users of the weigh station.

To further examine this observation, the proportion of trucks in the traffic entering each of the three rest areas was calculated during these same time periods when the weigh stations were closed and open. As shown in Table 8, the proportion of trucks at all three sites notably increased when the weigh stations were in operation. However, the magnitude of this increase is not consistent among the sites. Specifically, the increases at sites 2 and 3 were more profound than that at site 1 . Overall, the results suggest that a weigh station in conjunction of a rest area will most likely increase the heavy vehicle demand on the rest area sharing the same location. 
The amount of the induced commercial truck demand is believed to be site specific and needs to be estimated on a case-by-case basis.

\section{Rest Area Condition}

Rest area condition was investigated in this research as one of the variables that may have an effect on rest area traffic usage. Rest area conditions were classified as being in good, fair, and poor condition. A good condition rest area was defined as one of newer construction and well maintained. Fair condition was likely to be of older construction and kept adequately maintained. Poor condition was likely older and nearing the end of its useful life. The process of determining the rest area condition using the previous conventions (rules) is highly subjective and relies heavily on judgment. The research found that rest areas classified as being in "good" condition were associated with higher usage (average of 16.9 percent of mainline traffic entering) than those classified as being in "poor" (average of 11.2 percent of mainline traffic entering) or "fair" (average of 10.4 percent of mainline traffic entering) condition.

To further examine the effect of rest area condition on traffic usage, the mean usage is provided for the four highway categories as shown in Table 9. Rest area usage for "good" condition is higher than that for the combined poor and fair conditions at high-volume interstate and low volume arterial categories, about the same for high-volume arterial, and slightly lower for low-volume interstate. This suggests the lack of adequate and consistent evidence about the effect of rest area condition on traffic usage.

\section{Seasonal Variation in Rest Area Usage}

In this research, rest area traffic usage data were collected during the peak summer travel season. In using these percentages for the planning and design of rest areas, it is important to use mainline traffic counts which represent the peak summer season.

\section{Patron Demand on Rest Area Facilities}

One indirect use of vehicle count data is a determination of the number of rest area patrons. Such information is important in the sizing of rest area facilities, from the size of the overall building(s) to specifics such as restroom fixtures. This research established the relationship between the number of vehicles accessing the rest area facility and the number of patrons using the rest area building at the four control station sites.

Based on this analysis, a value of 1.5 patrons per vehicle accessing the rest area facility is reasonable to recommend for use in rest area design. This figure is considered conservative as it is slightly higher than the values observed at all rest areas except the low volume arterial rest area where the corresponding value was 1.78 patrons per vehicle. This higher value is believed to be related to the highly recreational traffic and the abnormally low percentage of trucks associated with this particular category of rest areas.

\section{Water Usage at Rest Areas}

The analysis of the average amount of water used and wastewater generated per patron at a rest area was also examined by this research. This was accomplished by dividing a specific day's water meter reading by the number of patrons at the rest area for that day. A summary of the results of this analysis is provided in Table 10.

The differences in water usage between rest areas on interstate and arterial highways are relatively small. Therefore, the overall statistics are more important to the discussion of water usage. As shown in this table, the average patron water usage at all rest areas is approximately 
1.5 gallons and the $85^{\text {th }}$ percentile water usage at all rest areas is 2.5 gallons per patron. As more up-to-date low-flow fixtures (used in all current rest area projects) normally result in lower water usage, and the fact that the statistics shown in this table are based on all rest areas including some of the older fixtures with higher water usage, it is reasonable to recommend average water usage per patron of 2.5 gallons for planning and design purposes.

\section{SUMMARY OF GUIDELINES ON REST AREA USAGE ESTIMATION}

Study results presented in the previous section suggest the following guidelines in the planning and design of rest areas particularly those located in rural areas:

- Guideline \#1: In rest area design, a baseline rest area usage of $16 \%$ and $25 \%$ of mainline peak traffic may be used at rest areas on interstate highways and rural arterials, respectively. This roughly corresponds to the $85^{\text {th }}$ percentile rest area traffic usage. A more conservative design may adopt a higher percentile value.

- Guideline \#2: There is no need to adjust the baseline rest area usage for the peak daytime period based on the overall percentage of heavy vehicles in the mainline served by the rest area.

- Guideline \#3: For planning and design purposes, it is reasonable to assume the percentage of heavy vehicles during the daytime design peak period and the nighttime off-peak period as equivalent to 70 percent and 200 percent of the overall heavy vehicle percentage for the mainline served by the rest area respectively. In this research, the former period corresponds to the period between 9:00 AM and 4:00 PM while the latter period corresponds to the period between midnight and 6:00 AM.

- Guideline \#4: Passenger vehicle traffic counts and average dwell time during the daytime peak period should be used in the determination of passenger car parking needs at the rest area.

- Guideline \#5: Both commercial vehicle counts and dwell times during the daytime peak period and the nighttime off-peak period should be used in determining truck parking needs at the rest area.

- Guideline \#6: A weigh station sharing the site with a rest area will most likely increase the commercial truck demand on the rest area when weigh station is in operation. The amount of the induced heavy vehicle demand needs to be estimated on a case-by-case basis.

- Guideline \#7: While rest area condition may affect traffic usage, it is recommended not to adjust the baseline usage for rest area condition due to lack of consistent empirical evidence.

- Guideline \#8: For rest area planning and design purposes, it is important to use mainline traffic counts that reflect the peak summer season.

- Guideline \# 9: For rest area planning and design purposes, a rate of 1.5 may be used in estimating the number of patrons using the rest area building based on the number of vehicles stopping at the rest area facility.

- Guideline \# 10: It is recommended that an average water usage of 2.5 gallons per patron be used in planning water and wastewater systems. The ultimate value employed will also need to conform to the requirements set forth by different state agencies (i.e. environmental) for the design of such systems, specifically wastewater treatment systems at sites where city sewer access is not available. 


\section{CLOSING REMARKS}

This paper has presented a series of practical guidelines that may be employed in the design and rehabilitation of rest area facilities, particularly those in rural areas. The guidance was developed using empirical observations of rest area usage aspects at 44 study sites in the state of Montana. Given the amount of data collected in support of this effort, it is reasonable to conclude that the developed guidelines are representative of a significant proportion of existing and future rest area sites in rural locales. Of course, each rest area is different and careful consideration should be given when employing the guidelines outlined in this paper.

Data already being collected by agencies is required in some cases in order to apply the guidelines, namely mainline traffic volumes and vehicle classifications present at the existing or perspective rest area site. If a site locale or setting differs significantly from those discussed and presented in this research, site-specific data should be considered.

While the current research developed several guidelines in regards to various aspects of rest area usage, it did not address some other rest area usage aspects. The authors would recommend investigating other variables that are thought to affect rest area usage, such as traffic mix by driver type, i.e. local versus non-local, and trip properties such as trip purpose and trip length. Further research on the effect of welcome and traveler information centers on rest area usage is also recommended, as the results of this study were inconclusive due to lack of adequate number of sites with information centers.

\section{ACKNOWLEDGEMENTS}

The authors wish to thank the Montana Department of Transportation for the funding of this research. They also wish to thank the project technical panel for their assistance and valuable input throughout the project.

\section{REFERENCES}

1. Task Force on Geometric Design. A Guide for the Development of Rest Areas on Major Arterials and Freeways, 3rd Edition. American Association of State Highway and Transportation Officials, Washington D.C., 2001.

2. King, G.F. Evaluation of Safety Roadside Rest Areas. National Cooperative Highway Research Program Report 324, December 1989.

3. Perfater, Michael A. Operation and Motorist Usage of Interstate Rest Areas and Welcome Centers in Virginia. In Transportation Research Record: Journal of the Transportation Research Board No. 1224, TRB, Washington D.C., 1989, pp. 46-53.

4. Melton, W., A. Tran and J. Leverson. Rest Area Usage Design Criteria Update. Washington State Department of Transportation, Olympia, Washington, January 1989.

5. Griffin, D. and X. Yan. Water Use, Waste Generation, and Traffic Counts at Interstate Rest Areas in Louisiana. Department of Civil Engineering - Louisiana Tech University, June, 2003.

6. Garder, P. and N. Bonosetto. Quantifying Roadside Rest Area Usage. New England Transportation Consortium, Project 99-4, November 2002.

7. Al-Kaisy, Ahmed, Zachary Kirkemo, David Veneziano, and Christopher Dorrington. Traffic Usage of Rest Areas on Rural Highways: A Recent Empirical Study. Accepted for Publication in Transportation Research Record, Journal of the Transportation Research Board, In Press. 
8. Nebraska Department of Roads. Nebraska Safety Rest Area Study Number 4. Nebraska Department of Roads, Lincoln, Nebraska, 1987.

9. Twardzik, L. and T. Haskell. Rest Area/Roadside Park Administration, Use and Operations. Michigan State University, Lansing, Michigan, June 1985.

10. Al-Kaisy, Ahmed, Brian Church, David Veneziano, and Christopher Dorrington. Investigation of Parking Dwell Time at Rest Areas on Rural Highways. Accepted for Publication in Transportation Research Record, Journal of the Transportation Research Board, In Press. 


\section{List of Tables and Figures}

FIGURE 1 Hourly rest area truck counts and percentages at the high and low volume interstate control site rest areas

TABLE 1 Summary of Rest Area Traffic Usage and Parking Dwell Time Literature

TABLE 2 Descriptive Statistics for Rest Area Traffic Usage Between 9:00 a.m. and 4:00 p.m.

TABLE 3 Mainline Heavy Vehicle Proportion versus Percent Rest Area Usage (all day)

TABLE 4 Mainline Heavy Vehicle Proportion versus Percent Rest Area Usage (8 a.m. - 8 p.m.)

TABLE 5 Mainline Heavy Vehicle Proportion versus Percent Rest Area Usage

TABLE 6 Mean Dwell Time by Vehicle Type During Day and Night at Study Sites

TABLE 7 Comparison of Rest Area Usage with Weigh Station Operation

TABLE 8 Comparison of Rest Area Count Truck Percentage with and without Weigh Station Operation

TABLE 9 Rest Area Usage by Condition and Highway Category

TABLE 10 Water Usage Summary of Results 
TABLE 1 Summary of Rest Area Traffic Usage and Parking Dwell Time Literature

\begin{tabular}{|c|c|c|c|c|}
\hline \multicolumn{5}{|c|}{ Usage Literature } \\
\hline Document & Year & Location & Usage Results & Sample Size \\
\hline AASHTO (1) & 2001 & $\begin{array}{l}\text { Minnesota, Virginia, } \\
\text { Washington }\end{array}$ & $\begin{array}{l}\text { Welcome center - } 12 \text { to } 15 \text { percent } \\
\text { Recreational routes }-8 \text { to } 13 \text { percent } \\
\text { Broad-use routes }-5.5 \text { to } 9 \text { percent }\end{array}$ & Unspecified \\
\hline King (2) & 1989 & Unspecified & $\begin{array}{l}\text { Between } 5.5 \text { and } 17.7 \text { percent ( } 10.3 \text { percent } \\
\text { average) } \\
\text { Average vehicle occupancy - } 2.2 \text { persons }\end{array}$ & 13 sites \\
\hline Perfater (3) & 1989 & Virginia & $\begin{array}{l}\text { Passenger cars - } 12 \text { percent } \\
\text { Heavy vehicles }-23 \text { percent }\end{array}$ & 11 sites \\
\hline Melton et.al. (4) & 1989 & Washington & $\begin{array}{l}\text { Average days - } 6 \text { and } 21.5 \text { percent } \\
\text { Peak periods }-7.5 \text { and } 44 \text { percent }\end{array}$ & Unspecified \\
\hline Griffin and Yan (5) & 2003 & Louisiana & Between 2 to 20 percent & 4 sites \\
\hline Garder and Bonosetto(6) & 2002 & $\begin{array}{l}\text { New Hampshire, Vermont, } \\
\text { Massachusetts, Maine }\end{array}$ & $\begin{array}{l}\text { New Hampshire }-3.2 \text { and } 12.05 \text { percent } \\
\text { Vermont }-7.7 \text { and } 14.4 \text { percent } \\
\text { Massachusetts } 1.7 \text { percent } \\
\text { Maine - } 0.5 \text { to } 6.9 \text { percent }\end{array}$ & $\begin{array}{l}\text { New Hampshire - } 4 \text { sites } \\
\text { Vermont - } 3 \text { sites } \\
\text { Massachusetts - } 1 \text { site } \\
\text { Maine - } 1 \text { site }\end{array}$ \\
\hline Al-Kaisy, et.al (7) & $\begin{array}{l}2009- \\
2010\end{array}$ & Montana & $\begin{array}{l}\text { High volume interstate }-10.1 \text { percent } \\
\text { low volume interstate }-8.4 \text { percent } \\
\text { High volume arterial }-9.6 \text { percent } \\
\text { Low volume arterial }-12.3 \text { percent } \\
\end{array}$ & 44 sites \\
\hline \multicolumn{5}{|c|}{ Dwell Time Literature } \\
\hline Document & Year & Location & Dwell Time Results & Sample Size \\
\hline King (2) & 1989 & Unspecified & $\begin{array}{l}\text { Average - } 11.4 \text { minutes } \\
\text { Standard deviation - } 12.87 \text { minutes } \\
\text { Minimum duration - } 1 \text { minute } \\
\text { Maximum duration - } 3 \text { hours } 31 \text { minutes } \\
\text { Passenger cars - } 11 \text { minutes } \\
\text { Heavy vehicles } 12.1 \text { minutes } \\
\text { Recreational vehicles - } 19.5 \text { minutes }\end{array}$ & 9 sites \\
\hline Perfater (3) & 1989 & Virginia & $\begin{array}{l}\text { Passenger cars - } 9.1 \text { minutes (10 minutes in } \\
\text { summer) } \\
\text { Heavy vehicles - } 15 \text { minutes }\end{array}$ & 11 sites \\
\hline $\begin{array}{l}\text { Nebraska Department of } \\
\text { Roads (8) }\end{array}$ & 1987 & Nebraska & $\begin{array}{l}\text { Passenger vehicles }-15.5 \text { minutes } \\
\text { Heavy vehicles }-30.4 \text { minutes } \\
\text { Recreational vehicles }-23.6 \text { minutes }\end{array}$ & Unspecified \\
\hline Twardzik and Haskell (9) & 1985 & Michigan & $\begin{array}{l}\text { Passenger vehicles - } 6.7 \text { minutes (winter), } \\
10.1 \text { minutes (summer) } \\
\text { Heavy vehicles - } 12.6 \text { minutes (winter), } 14.6 \\
\text { minutes (summer) }\end{array}$ & 6 sites \\
\hline Al-Kaisy, et.al (10) & 2009 & Montana & $\begin{array}{l}\text { Passenger vehicles - } 10-16 \text { minutes } \\
\text { Heavy vehicles }-37-77 \text { minutes } \\
\text { Recreational vehicles }-16-25 \text { minutes }\end{array}$ & 3 sites \\
\hline
\end{tabular}


TABLE 2 Descriptive Statistics for Rest Area Traffic Usage Between 9:00 a.m. and 4:00 p.m.

\begin{tabular}{|c|c|c|c|c|c|c|c|c|}
\hline Mean & Median & Mode & $\begin{array}{c}\text { Standard } \\
\text { De viation }\end{array}$ & $\begin{array}{c}\text { 80th } \\
\text { Percentile }\end{array}$ & $\begin{array}{c}85 \text { th } \\
\text { Percentile }\end{array}$ & $\begin{array}{c}\text { 90th } \\
\text { Percentile }\end{array}$ & $\begin{array}{c}\text { 95th } \\
\text { Percentile }\end{array}$ & Range \\
\hline \multicolumn{9}{|c|}{ High Volume Interstate $($ ADT $=510$, sample size $=18)$} \\
\hline 11.45 & 10.86 & 9 & 6.48 & 15.25 & 16.62 & 19.36 & 24.38 & $1.12-36.91$ \\
\hline \multicolumn{9}{|c|}{ Low Volume Interstate $(\mathrm{ADT}=228$, sample size $=12)$} \\
\hline 10.36 & 9.83 & 9 & 4.55 & 14.01 & 15.06 & 16.36 & 17.87 & $2.09-29.52$ \\
\hline \multicolumn{9}{|c|}{ High Volume Arterial $($ ADT $=366$, sample size $=4)$} \\
\hline 13.36 & 11.74 & 6 & 7.63 & 20.6 & 22.41 & 22.41 & 24.34 & $1.37-35.84$ \\
\hline \multicolumn{9}{|c|}{ Low Volume Arterial $(\mathrm{ADT}=195$, sample size $=10)$} \\
\hline 16.17 & 11.38 & 7 & 12.64 & 22.68 & 28.57 & 35.51 & 46.59 & $1.2-59.74$ \\
\hline \multicolumn{9}{|c|}{ Interstate $(\mathrm{ADT}=397$, sample size $=30)$} \\
\hline 11.02 & 10.42 & 9 & 5.82 & 14.73 & 16.01 & 17.72 & 22.56 & $1.12-36.91$ \\
\hline \multicolumn{9}{|c|}{ Arterial $(\mathrm{ADT}=244$, sample size $=14)$} \\
\hline 15.39 & 11.46 & 8 & 11.52 & 21.36 & 25.63 & 31.75 & 43.6 & $1.12-59.74$ \\
\hline \multicolumn{9}{|c|}{ Overall $(\mathrm{ADT}=348$, sample size $=44)$} \\
\hline 12.4 & 10.7 & 9 & 8.32 & 15.98 & 18.32 & 22.25 & 28.5 & $1.12-59.74$ \\
\hline
\end{tabular}


TABLE 3 Mainline Heavy Vehicle Proportion versus Percent Rest Area Usage (all day)

\begin{tabular}{|l|c|c|c|c|c|}
\hline$\%$ Heavy Vehicles & 0 to 10 & 10 to 20 & 20 to 30 & 30 to 40 & $40+$ \\
\hline \multicolumn{7}{|c|}{ High Volume Interstate (2009 average \% trucks = 22.9\%) } \\
\hline$\%$ Rest Area Usage & 11.8 & 10.3 & 9.8 & 11.5 & 14.5 \\
\hline \multicolumn{6}{|c|}{ Low Volume Interstate (2009 average \% trucks = 22.2\%) } \\
\hline \% Rest Area Usage & 12.3 & 11.3 & 9.4 & 9.4 & 10.1 \\
\hline
\end{tabular}


TABLE 4 Mainline Heavy Vehicle Proportion versus Percent Rest Area Usage (8 a.m. -8 p.m.)

\begin{tabular}{|l|c|c|c|c|}
\hline \% Heavy Vehicles & 0 to 10 & 10 to 20 & 20 to 30 & $30+$ \\
\hline \multicolumn{5}{|c|}{ High Volume Interstate (2009 average \% trucks = 21.2\%) } \\
\hline \% Rest Area Usage & 10.1 & 11.0 & 10.8 & -- \\
\hline \multicolumn{6}{|c|}{ Low Volume Interstate (2009 average \% trucks $=\mathbf{1 9 . 4 \% )}$} \\
\hline \% Rest Area Usage & 12.7 & 12.4 & 11.0 & $14.3 *$ \\
\hline
\end{tabular}

*This value came from only 8 observations. 
TABLE 5 Mainline Heavy Vehicle Proportion versus Percent Rest Area Usage

\begin{tabular}{|l|c|c|c|c|c|}
\hline Location & $\begin{array}{c}\text { Peak Period } \\
\text { \% Heavy } \\
\text { Vehicles }\end{array}$ & $\begin{array}{c}\text { Overall \% } \\
\text { Heavy } \\
\text { Vehicles }\end{array}$ & $\begin{array}{c}\text { Peak-to- } \\
\text { Overall } \\
\text { Ratio }\end{array}$ & $\begin{array}{c}\text { Night Hours } \\
\text { (12 a.m. - } \\
\text { 6 a.m.) }\end{array}$ & $\begin{array}{c}\text { Night-to- } \\
\text { Overall } \\
\text { Ratio }\end{array}$ \\
\hline $\begin{array}{l}\text { Low Volume } \\
\text { Interstate }\end{array}$ & 12.5 & 22.2 & 0.563 & 35.5 & 1.601 \\
\hline $\begin{array}{l}\text { Low Volume } \\
\text { Arterial }\end{array}$ & 2.2 & 3.0 & 0.743 & 6.4 & 2.14 \\
\hline $\begin{array}{l}\text { High Volume } \\
\text { Interstate }\end{array}$ & 14.7 & 22.4 & 0.655 & 35.9 & 1.603 \\
\hline
\end{tabular}




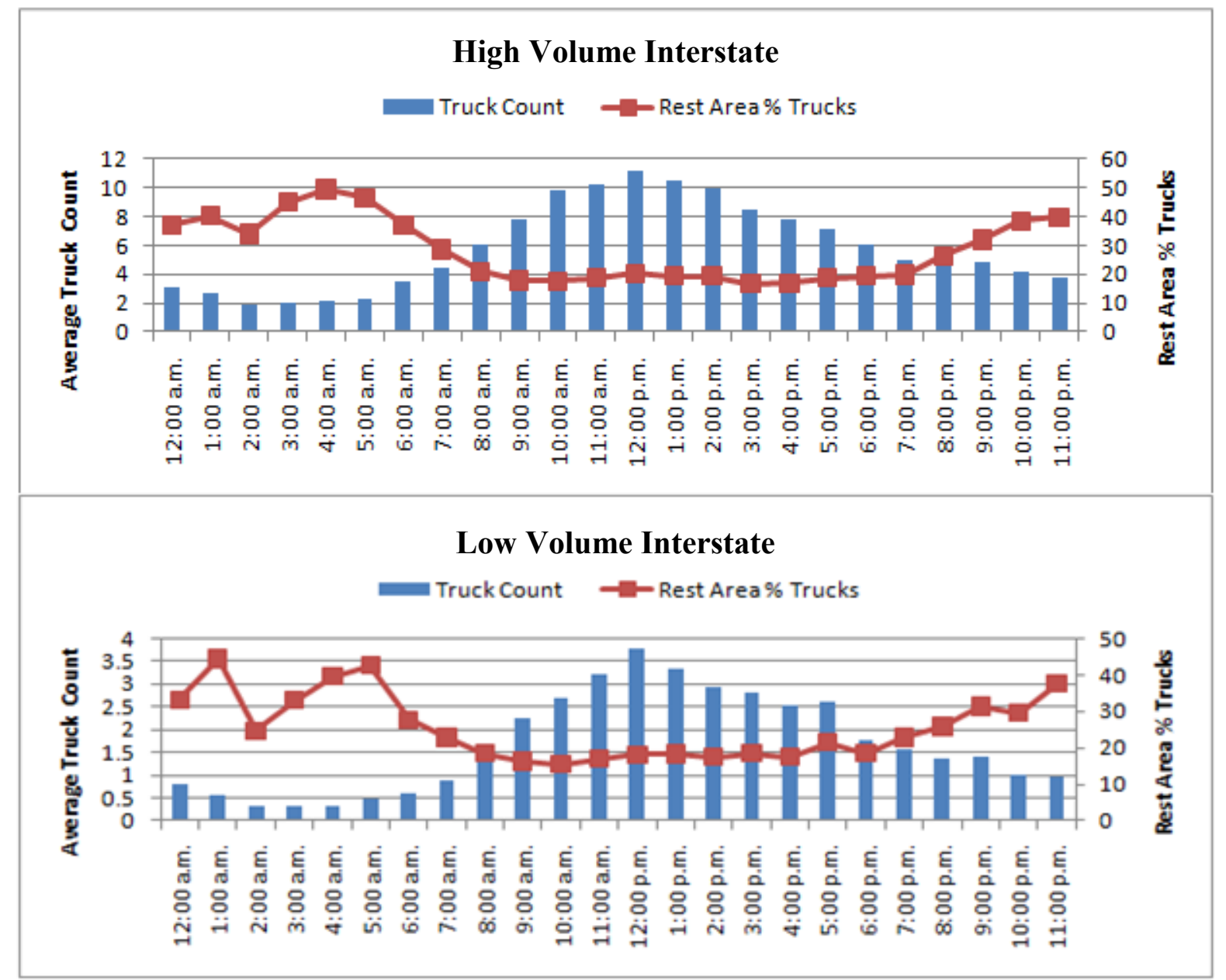

FIGURE 1 Hourly rest area truck counts and percentages at the high and low volume interstate control site rest areas 
TABLE 6 Mean Dwell Time by Vehicle Type During Day and Night at Study Sites

\begin{tabular}{|l|c|c|c|}
\hline \multicolumn{4}{|c|}{ Mean Dwell Time (Hr: Min: Sec) } \\
\hline \multicolumn{1}{|c|}{ Location } & Vehicle Type & Day & Night \\
\hline \multirow{2}{*}{$\begin{array}{l}\text { High Volume } \\
\text { Interstate }\end{array}$} & Cars & $00: 10: 31$ & $01: 13: 35$ \\
\cline { 2 - 4 } & Trucks & $00: 34: 00$ & $03: 08: 00$ \\
\cline { 2 - 4 } & RVs & $00: 15: 37$ & $03: 45: 00$ \\
\hline \multirow{2}{*}{$\begin{array}{l}\text { Low Volume } \\
\text { Interstate }\end{array}$} & Cars & $00: 10: 47$ & $00: 50: 14$ \\
\cline { 2 - 4 } & Trucks & $00: 37: 50$ & $03: 21: 42$ \\
\hline \multirow{2}{*}{$\begin{array}{l}\text { High Volume } \\
\text { Arterial }\end{array}$} & Cars & $00: 14: 44$ & $01: 07: 04$ \\
\cline { 2 - 4 } & Trucks & $00: 09: 33$ & $00: 22: 18$ \\
\cline { 2 - 4 } & RVs & $0025: 25$ & $01: 36: 22$ \\
\hline
\end{tabular}

--- Value omitted for lack of adequate empirical observations. 
TABLE 7 Comparison of Rest Area Usage with Weigh Station Operation

\begin{tabular}{|l|c|c|c|}
\hline Rest Area Site & $\begin{array}{c}\text { Weigh Station } \\
\text { Closed }\end{array}$ & $\begin{array}{c}\text { Weigh Station } \\
\text { Open }\end{array}$ & $\begin{array}{c}\text { Hours of } \\
\text { Operation }\end{array}$ \\
\hline Site 1 & $10.3 \%$ & $10.1 \%$ & 9 a.m. to 5 p.m. \\
\hline Site 2 & $8.7 \%$ & $18.5 \%$ & 10 a.m. to 3 p.m. \\
\hline Site 3 & $13.1 \%$ & $50.8 \%$ & 9 a.m. to 4 p.m. \\
\hline
\end{tabular}


TABLE 8 Comparison of Rest Area Count Truck Percentage with and without Weigh Station Operation

\begin{tabular}{|l|c|c|c|}
\hline Rest Area Site & $\begin{array}{c}\text { Weigh Station } \\
\text { Closed }\end{array}$ & $\begin{array}{c}\text { Weigh Station } \\
\text { Open }\end{array}$ & $\begin{array}{c}\text { Hours of } \\
\text { Operation }\end{array}$ \\
\hline Site 1 & $10.3 \%$ & $10.1 \%$ & 9 a.m. to 5 p.m. \\
\hline Site 2 & $8.7 \%$ & $18.5 \%$ & 10 a.m. to 3 p.m. \\
\hline Site 3 & $13.1 \%$ & $50.8 \%$ & 9 a.m. to 4 p.m. \\
\hline
\end{tabular}


TABLE 9 Rest Area Usage by Condition and Highway Category

\begin{tabular}{|l|c|c|c|}
\hline Category & Poor/Fair & Good & $\begin{array}{c}\text { Good-to-Poor/Fair } \\
\text { Ratio }\end{array}$ \\
\hline High-Volume Interstate & 9.4 & 11.0 & 1.17 \\
\hline Low-Volume Interstate & 8.8 & 7.9 & 0.90 \\
\hline High-Volume Arterial & 9.0 & 9.3 & 1.03 \\
\hline Low-Volume Arterial & 11.4 & 16.2 & 1.42 \\
\hline
\end{tabular}


TABLE 10 Water Usage Summary of Results

\begin{tabular}{|l|r|r|r|r|r|}
\hline & \multicolumn{1}{|c|}{$\begin{array}{c}\text { Mean } \\
\text { (gal/patron) }\end{array}$} & $\begin{array}{c}\text { Median } \\
\text { (gal/patron) }\end{array}$ & $\begin{array}{c}\mathbf{8 5}^{\text {th }} \\
\text { Percentile }\end{array}$ & \multicolumn{1}{c|}{$\begin{array}{c}\mathbf{9 0}^{\text {th }} \\
\text { Percentile }\end{array}$} & $\begin{array}{c}\mathbf{9 5}^{\text {th }} \\
\text { Percentile }\end{array}$ \\
\hline Interstate & 1.45 & 1.24 & 2.53 & 2.84 & 3.32 \\
\hline Arterial & 1.46 & 1.25 & 2.36 & 2.58 & 3.00 \\
\hline Overall & 1.45 & 1.24 & 2.5 & 2.8 & 3.26 \\
\hline
\end{tabular}

